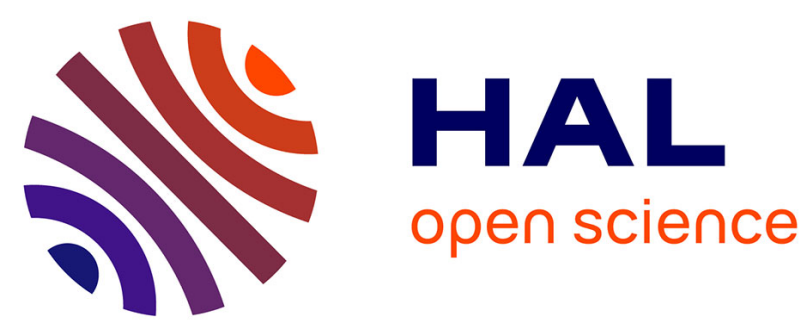

\title{
CH4 production and oxidation processes in a boreal fen ecosystem after long-term water table drawdown
}

Kim Yrjälä, Tero Tuomivirta, Heli Juottonen, Anuliina Putkinen, Kaisa

Lappi, Eeva-Stiina Tuittila, Timo Penttilä, Kari Minkkinen, Jukka Laine, Krista Peltoniemi, et al.

\section{To cite this version:}

Kim Yrjälä, Tero Tuomivirta, Heli Juottonen, Anuliina Putkinen, Kaisa Lappi, et al.. CH4 production and oxidation processes in a boreal fen ecosystem after long-term water table drawdown. Global Change Biology, 2010, 17 (3), pp.1311. 10.1111/j.1365-2486.2010.02290.x . hal-00599524

\section{HAL Id: hal-00599524 https://hal.science/hal-00599524}

Submitted on 10 Jun 2011

HAL is a multi-disciplinary open access archive for the deposit and dissemination of scientific research documents, whether they are published or not. The documents may come from teaching and research institutions in France or abroad, or from public or private research centers.
L'archive ouverte pluridisciplinaire HAL, est destinée au dépôt et à la diffusion de documents scientifiques de niveau recherche, publiés ou non, émanant des établissements d'enseignement et de recherche français ou étrangers, des laboratoires publics ou privés. 


\section{Global Change Biology}

\section{CH4 production and oxidation processes in a boreal fen ecosystem after long-term water table drawdown}

\begin{tabular}{|c|c|}
\hline Journal: & Global Change Biology \\
\hline Manuscript ID: & GCB-10-0362 \\
\hline Wiley - Manuscript type: & Primary Research Articles \\
\hline $\begin{array}{r}\text { Date Submitted by the } \\
\text { Author: }\end{array}$ & 04-May-2010 \\
\hline Complete List of Authors: & $\begin{array}{l}\text { Yrjälä, Kim; University of Helsinki, Department of Biosciences } \\
\text { Tuomivirta, Tero; Finnish Forest Research Institute, Southern Unit } \\
\text { Juottonen, Heli; University of Helsinki, Department of Biosciences } \\
\text { Putkinen, Anuliina; Finnish Forest Research Institute, Southern } \\
\text { Unit; University of Helsinki, Department of Biosciences } \\
\text { Lappi, Kaisa; University of Helsinki, Department of Biosciences } \\
\text { Tuittila, Eeva-Stiina; University of Helsinki, Department of Forest } \\
\text { Sciences } \\
\text { Penttilä, Timo; Finnish Forest Research Institute, Southern Unit } \\
\text { Minkkinen, Kari; University of Helsinki, Department of Forest } \\
\text { Sciences } \\
\text { Laine, Jukka; Finnish Forest Research Institute, Western Unit } \\
\text { Peltoniemi, Krista; Finnish Forest Research Institute, Southern Unit } \\
\text { Fritze, Hannu; Finnish Forest Research Institute, Southern Unit }\end{array}$ \\
\hline Keywords: & $\begin{array}{l}\text { greenhouse gas, peatlands, methanogens, methanotrophs, } \\
\text { microbial community, DGGE, T-RFLP }\end{array}$ \\
\hline Abstract: & $\begin{array}{l}\text { Mires, especially sedge dominated fens, are sources of the } \\
\text { greenhouse gas CH4. Climate change scenarios predict a lowering } \\
\text { water table (WT) in mires. To study the effect of WT drawdown on } \\
\mathrm{CH} 4 \text { dynamics in a fen ecosystem, we took advantage of a WT } \\
\text { drawdown gradient near a ground water extraction plant. Methane } \\
\text { fluxes, CH4 production and oxidation potentials, were related to } \\
\text { microbial communities responsible for the processes in four mire } \\
\text { locations (wet, semi-wet, semi-dry and dry). Principal component } \\
\text { analyses (PCA) performed on the vegetation, pH, CH4 and WT } \\
\text { results clearly separated the four sampling locations in the } \\
\text { gradient. Long-term lowering of WT was associated with decreased } \\
\text { coverage of Sphagnum and aerenchymatic plants, decreased CH4 } \\
\text { field emissions and CH4 production potential. Based on mcrA T-RF } \\
\text { the methanogen community structure correlated best with the } \\
\text { methane production and coverage of aerenchymatic plants along } \\
\text { the gradient. Methanosarcinaceae and Methanocellales were found } \\
\text { at the pristine wet end of the gradient, whereas the Fen cluster }\end{array}$ \\
\hline
\end{tabular}


Page 1 of 38

Global Change Biology

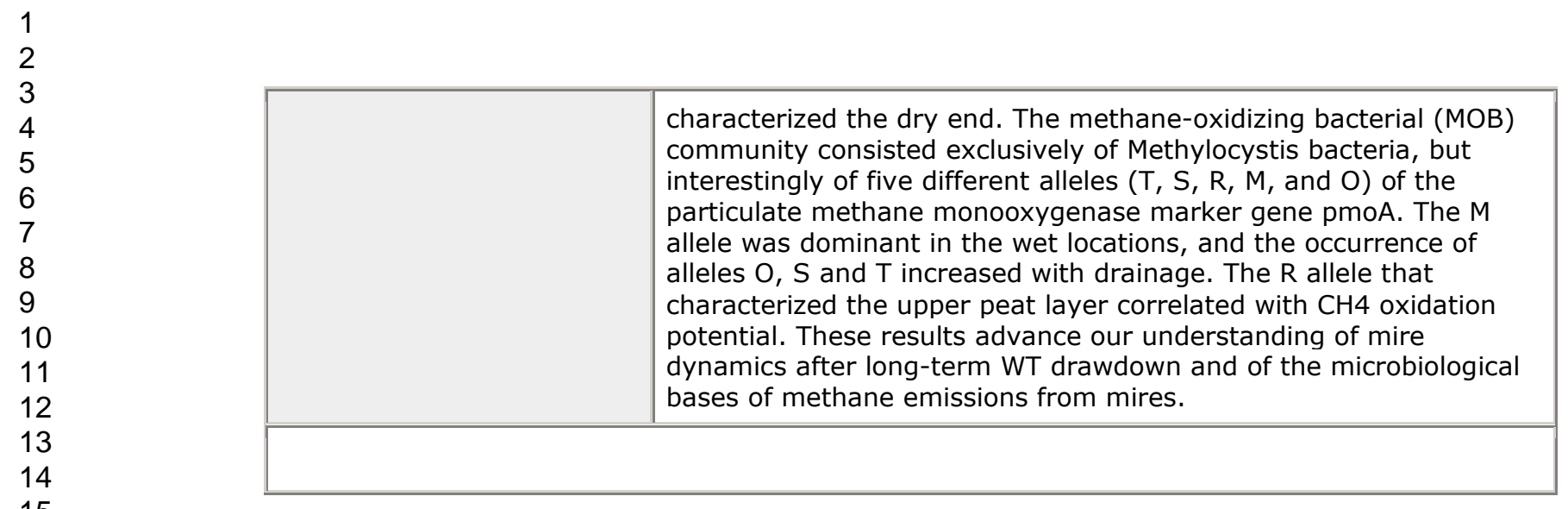

15

16

17

18

19

20

21

22

23

24

25

26

27

28

29

30

31

32

33

34

35

36

37

38

39

40

41

42

43

44

45

46

47

48

49

50

51

52

53

54

55

56

57

58

59

60 


\section{$\mathrm{CH}_{4}$ production and oxidation processes in a boreal fen ecosystem after long-term water table drawdown}

\section{Running title: $\mathrm{CH}_{4}$ production and oxidation processes}

Kim Yrjälä ${ }^{1}$, Tero Tuomivirta ${ }^{2}$, Heli Juottonen ${ }^{1}$, Anuliina Putkinen ${ }^{1,2}$, Kaisa Lappi ${ }^{1}$, Eeva-Stiina Tuittila $^{3}$, Timo Penttilä ${ }^{2}$, Kari Minkkinen ${ }^{3}$, Jukka Laine ${ }^{4}$, Krista Peltoniemi $^{2}$, Hannu Fritze $^{2}$

${ }^{1}$ MEM-group, Department of Biosciences, PO Box 56, 00014 University of Helsinki, Finland

${ }^{2}$ Finnish Forest Research Institute, Southern Unit, PO Box 18, 01301 Vantaa, Finland

${ }^{3}$ Peatland Ecology Group, Department of Forest Sciences, PO Box 27, 00014 University of Helsinki, Finland

${ }^{4}$ Finnish Forest Research Institute, Western Unit, Kaironiementie 54, 39700 Parkano, Finland

Corresponding author: Kim Yrjälä; Tel. +358 (0)9-19159220; Fax, +358 (0)9-19159262; E-mail: kim.yrjala@helsinki.fi

Keywords: greenhouse gas, peatlands, methanogens, methanotrophs, microbial communities, DGGE, T-RFLP 


\section{Abstract}

Mires, especially sedge dominated fens, are sources of the greenhouse gas $\mathrm{CH}_{4}$. Climate change scenarios predict a lowering water table (WT) in mires. To study the effect of WT drawdown on $\mathrm{CH}_{4}$ dynamics in a fen ecosystem, we took advantage of a WT drawdown gradient near a ground water extraction plant. Methane fluxes, $\mathrm{CH}_{4}$ production and oxidation potentials, were related to microbial communities responsible for the processes in four mire locations (wet, semi-wet, semidry and dry). Principal component analyses (PCA) performed on the vegetation, $\mathrm{pH}, \mathrm{CH}_{4}$ and WT results clearly separated the four sampling locations in the gradient. Long-term lowering of WT was associated with decreased coverage of Sphagnum and aerenchymatic plants, decreased $\mathrm{CH}_{4}$ field emissions and $\mathrm{CH}_{4}$ production potential. Based on $m c r A \mathrm{~T}-\mathrm{RF}$ the methanogen community structure correlated best with the methane production and coverage of aerenchymatic plants along the gradient. Methanosarcinaceae and Methanocellales were found at the pristine wet end of the gradient, whereas the Fen cluster characterized the dry end. The methane-oxidizing bacterial (MOB) community consisted exclusively of Methylocystis bacteria, but interestingly of five different alleles (T, S, R, M, and $\mathrm{O}$ ) of the particulate methane monooxygenase marker gene pmoA. The $\mathrm{M}$ allele was dominant in the wet locations, and the occurrence of alleles $\mathrm{O}, \mathrm{S}$ and $\mathrm{T}$ increased with drainage. The $\mathrm{R}$ allele that characterized the upper peat layer correlated with $\mathrm{CH}_{4}$ oxidation potential. These results advance our understanding of mire dynamics after long-term WT drawdown and of the microbiological bases of methane emissions from mires. 


\section{Introduction}

In the Northern hemisphere mires extend over vast areas that typically are water-saturated ecosystems where a part of the plant litter production avoids aerobic decomposition and accumulates as peat. The high water table (WT) creates anaerobic microbial habitats where methanogenesis occurs (Rydin et al. 2006). Hence boreal mires act as methane $\left(\mathrm{CH}_{4}\right)$ sources into the atmosphere. Due to climate change, a growing attention has been devoted to these areas, where over one-third of the global terrestrial carbon is stored (Gorham, 1991). The rise of earth temperatures may have profound effects on the microbial life of these ecosystems and thus on microbially-mediated gas emissions (IPCC 2007).

Methane, which is a 25 times more powerful greenhouse gas than carbon dioxide, is produced microbiologically in the final stage of anaerobic degradation of organic matter (Whalen, 2005). Methane is solely produced by methanogens that are classified into Euryarchaeota. Methanogens are highly diverse constituting of four classes and six orders of archaea. Methane-producing archaeal communities have been described from various mire ecosystems (Edwards et al. 1998; Basiliko et al. 2003; Galand et al. 2003; Galand et al. 2005; Galand et al. 2005; Juottonen et al. 2008; Putkinen et al. 2009) including a range of nutrient conditions (Juottonen et al. 2005) and mire successional stages (Merilä et al. 2006). Methanogens of Methanosarcinales, Methanomicrobiales, Methanobacteriales and Methanocellales (Rice cluster I) have frequently been detected.

The $\mathrm{CH}_{4}$ emissions are, however, dependent on the activity and abundance of methaneoxidizing bacteria (MOB) that are able to oxidize $\mathrm{CH}_{4}$ to $\mathrm{CO}_{2}$ in aerobic conditions (Hanson and Hanson 1996). The aerobic layer of peat is roughly defined by the WT position (Bubier \& Moore, 1993). Low emissions in mires can occur when the $\mathrm{CH}_{4}$ never reaches the atmosphere because it is consumed by MOB in the uppermost aerobic layer (Whalen, 2005). In this way the $\mathrm{CH}_{4}$ flux to 
the atmosphere is the sum of the functionally opposite actions of archaea and bacteria involved in the $\mathrm{CH}_{4}$ cycle. The highest MOB activity in mires is observed just above the WT, where $\mathrm{CH}_{4}$ and oxygen levels are adequate for $\mathrm{CH}_{4}$ oxidation (Sundh et al. 1994). While estimates of the oxidation efficiency of the produced $\mathrm{CH}_{4}$ in different mires vary considerably, estimates of between 20\% in Carex dominated fens (Popp et al. 2000) and 78\% in Sphagnum dominated bogs (Yavitt et al. 1988) have been given. The latter phenomena is explained by the fact that MOB inhabit Sphagnum species providing the plant $\mathrm{CO}_{2}$ through $\mathrm{CH}_{4}$ oxidation under wet conditions (Raghoebarsing et al. 2005; Larmola et al. 2010).

MOB are traditionally divided into two taxonomic groups, type I and II, within the Proteobacteria. Type I MOB includes genera like Methylobacter and Methylomicrobium, which belong to the Gammaproteobacteria. The type II MOB, Methylocystis, Methylosinus, Methylocella and Methylocapsa belong to the Alphaproteobacteria (Hanson \& Hanson 1996; Dedysh, 2009). These types differ in their carbon assimilation pathway, phylogenetic affiliation, and intracellular membrane arrangement.

The methanogenic and methanotrophic communities in Finnish mires have been studied by molecular genetic methods. Methanogens were analyzed by using both functional, $m c r A$ (Galand et al. 2002a), and phylogenetic 16S rRNA marker genes (Galand et al. 2003). MOB have been studied by functional ( $p m o A)$ marker gene analysis in a pristine and drained fen and bog within a mire complex (Jaatinen et al. 2005). The fingerprinting of Finnish fen MOB was improved by modifications of the pmoA reverse primer for DGGE analysis protocols (Tuomivirta et al. 2009). Methanogens and methanotrophs in mires have, however, rarely been analyzed within the same study (McDonald et al. 1999).

The $\mathrm{CH}_{4}$ turnover in mires is highly dependent on the ecohydrological conditions. In climate change scenarios where the raise of temperature is $3{ }^{\circ} \mathrm{C}$, the summertime WT in northern 
mires is expected to drop 10-20 cm (Gorham 1991; Roulet et al. 1992; Gitay et al. 2001). A WT drawdown of that magnitude $(15 \mathrm{~cm})$ has occurred in the northern Suonukkasuo fen where a groundwater extraction plant has generated a WT gradient that has gradually changed part of the wet fen into a forested peatland (Jaatinen et al. 2008). Such a persistent change in the WT influence the plant community structure (Weltzin et al. 2000; Weltzin et al. 2003) that may lead to complete replacement with species better adapted to the new conditions (Laine et al. 1995; Strack et al. 2006).

The WT gradient was studied combining methane gas flux measurements, environmental data and measurements of microbial communities responsible for $\mathrm{CH}_{4}$ turnover. This gradient study prompted the formulation of hypotheses concerning $\mathrm{CH}_{4}$ turnover in relation to detected microbial communities, namely: (1) as the WT drawdown affects the plant cover and stimulate tree growth, the $\mathrm{CH}_{4}$ emissions are reduced in the resulting dryer conditions; (2) the emissions in WT drawdown conditions decrease primarily as a consequence of decrease in potential $\mathrm{CH}_{4}$ production and simultaneous decrease in diversity of methanogens; (3) the potential $\mathrm{CH}_{4}$ oxidation decreases when there is less $\mathrm{CH}_{4}$ available; (4) the depth is an important factor determining microbial community structure, both that of methanogens and of methanotrophs; (5) there are specific types of methane-producing archaea and MOB that are favored by the WT drawdown.

\section{Materials and methods}

\section{Experimental site and sampling}

The study site, Suonukkasuo, is a mesotrophic pine fen located in Rovaniemi, northern Finland $\left(66^{\circ} 28^{\prime} \mathrm{N}, 25^{\circ} 51^{\prime} \mathrm{E}\right)$ within the aapa mire zone. Mesotrophic pine fens (RhSR in the Finnish mire 
site-type nomenclature of Laine and Vasander (2005)) are typically sites where wet lawns and drier hummocks form a mosaic-like vegetation pattern. A groundwater extraction plant on an esker bordering the mire downstream has affected the WT at the study site since 1959, resulting in a clear hydrological gradient where the pristine wet fen (location S4) becomes semi-wet (location S3), semi-dry (location S2), and finally a dry pine dominated mesotrophic peatland forest (MtkgII, location S1).

The average long term water-table (WT) values for the ground-frost free periods of the years 2001-2003 and 2005 expressed as distances from soil surface were 26, 21, 15 and $9 \mathrm{~cm}$ for the locations S1 to S4, respectively. The differences in WT between locations were statistically significant, except between locations $\mathrm{S} 1$ and $\mathrm{S} 2(\mathrm{p}=0.066)$. The first- and third-quartile ranges of the WTs were $21-30,13-30,10-21$ and 5-13 cm for the locations S1 to S4, respectively. The momentary WT at the time of sampling in 2006 was 32, 50, 47 and $23 \mathrm{~cm}$, respectively. The hydrological gradient is reflected in vegetation composition as reported in Jaatinen et al. (2008).

Sampling was conducted in September 2006. Intact triplicate peat cores were taken from the four locations using a corer (size $4 \times 6 \mathrm{~cm}$ ) to a depth of $70 \mathrm{~cm}$. Depth samples were prepared by dividing peat cores at $10 \mathrm{~cm}$ intervals. The samples between $0-50 \mathrm{~cm}$ depth were used for estimation of the methanotroph activity and community analyses and the samples between depths $20-70 \mathrm{~cm}$ for the respective analyses for methanogens. For convenience we call the samples between 0 to $10 \mathrm{~cm}$ as $0 \mathrm{~cm}$, between 10 to $20 \mathrm{~cm}$ as $10 \mathrm{~cm}$ and so on. To measure the peat dry weight subsamples were kept at $105^{\circ} \mathrm{C}$ for over $12 \mathrm{~h}$ and subsequently weighted.

\section{Field $\mathrm{CH}_{4}$ measurements}

Gas efflux measurement plots $(\mathrm{n}=3)$ were installed at each location in June 2001 (Dahlin et al., 2003). Collars made of metal tubes (diameter $31.5 \mathrm{~cm}$ ) were inserted $15-30 \mathrm{~cm}$ deep in peat. An 
aluminum groove was attached on the top of each collar. A closed chamber (height $30 \mathrm{~cm}$ ) equipped with a fan was placed on the groove filled with water before sampling to seal the chamber. At each sampling occasion, four successive samples of $30 \mathrm{ml}$ were taken from the chamber with plastic syringes during a 35-minute measurement period at 10 minute intervals (5, $15,25,35$ minutes). The syringes were then taken to laboratory and analyzed for $\mathrm{CH}_{4}$ concentrations within 24 hours from sampling by a gas chromatograph equipped with a FI detector. $\mathrm{CH}_{4}$ fluxes were calculated from a linear change of $\mathrm{CH}_{4}$ concentrations during the sampling period of 35 minutes. Obvious ebullition events were deleted from the data.

\author{
Measurements of potential $\mathrm{CH}_{4}$ production and oxidation \\ Measurements of potential $\mathrm{CH}_{4}$ production and oxidation $(4.13 \mu \mathrm{mol}$ in $125 \mathrm{ml}$ infusion bottle) \\ with incubation at $15{ }^{\circ} \mathrm{C}$ were carried out as described in Juottonen et al. (2008) and Jaatinen et \\ al. (2005), respectively.
}

\author{
Analysis of methanogen communities by mcrA-TRFLP \\ DNA for methanogen community analysis was extracted from $0.25 \mathrm{~g}$ of wet mass peat with \\ PowerSoil DNA Isolation Kit (MoBio Laboratories). Methyl coenzyme M reductase ( $m c r A$ ) gene \\ fragments were amplified with the primers of Luton et al. (2002). The reactions (50 $\mu \mathrm{l})$ contained \\ $1 \times$ PCR buffer with $2 \mathrm{mM} \mathrm{MgCl} 2$ (Biotools), $200 \mu \mathrm{M}$ dNTPs, $0.4 \mu \mathrm{M}$ of both primers, $1 \mathrm{U}$ of \\ DNA polymerase (Biotools), and 1-2 $\mu$ l of undiluted DNA extract as template. The reaction \\ conditions were initial denaturation $\left(94{ }^{\circ} \mathrm{C}, 3 \mathrm{~min}\right)$ followed by 31 cycles of $94{ }^{\circ} \mathrm{C} 45 \mathrm{~s}, 52{ }^{\circ} \mathrm{C} 1$ \\ $\min , 72{ }^{\circ} \mathrm{C} 1 \mathrm{~min} 30 \mathrm{~s}$, and a final elongation $\left(72{ }^{\circ} \mathrm{C}, 7 \mathrm{~min}\right)$. In PCR for T-RFLP, the forward \\ primer was 5'-labelled with 6-carboxyfluorescein (FAM).
}


For T-RFLP, approximately 25-50 ng of PCR products was digested with $3 \mathrm{U}$ of $M s p \mathrm{I}$ (Fermentas) at $37{ }^{\circ} \mathrm{C}$ overnight. The T-RFLP analysis was carried out as described in Juottonen et al. (2008). The range of fragment lengths included in the analysis was 75 to $500 \mathrm{bp}$. Minimum peak height threshold was 100 fluorescence units. Results are presented based on relative peak area. For identification of T-RFs, three clone libraries (S4 $20 \mathrm{~cm}$; S2 $30 \mathrm{~cm}$; S1 50cm) were constructed as in Juottonen et al. (2008). Inserts from clone colonies were re-amplified with $m c r A$ primers (33-54 clone per library) and screened by RFLP with MspI. From RFLP groups with $>5$ clones, $2-5$ clones from each group were sequenced, and from groups with $<5$ clones, one member was sequenced as in Juottonen et al. (2008). Terminal restriction fragments were identified based on in silico digestion of the sequences and T-RFLP analysis of clones.

\section{Investigation of MOB by DGGE analysis of the pmoA marker gene}

DNA for methane-oxidizing bacteria (MOB) community analysis was extracted from ca. $0.5 \mathrm{~g}$ wet mass peat using the FastDNA kit for soil (MP Biomedicals, Ohio, USA) according to Yeates \& Gillings (1998) modified as in Tuomivirta et al. (2009). A region of subunit $\alpha$ of particulate methane monooxygenase ( $p m o A)$ was PCR targeted with the A189f/A621r with a GC-clamp attached to the reverse primer (see Tuomivirta et al. 2009 for details). Also broad specificity A189f/A682r (Holmes et al. 1995) primers were applied for reference (Tuomivirta et al. 2009).

Fingerprinting of the MOB diversity was performed in a denaturing gradient gel electrophoresis (DGGE) described in Jaatinen et al. (2005). The DGGE gel photographs were screened for the presence (1) or absence (0) of pmoA bands using the AlphaImager 2.1 program of the AlphaDigiDoc gel documentation system (Alpha Innotech Corp., CA. US). A binary matrix was generated with this data using only the positions of successfully sequenced bands. 
Single DGGE bands of interest were excised from the gel, purified and sequenced as described in Tuomivirta et al. (2009) and Larmola et al. (2010).

\section{Sequence analysis and phylogeny}

$m c r A$ and $p m o A$ sequences were compared to database sequences with BLAST (Altschul et al. 1997) analysis of the National Center for Biotechnology Information (NCBI). Deduced amino acid sequences of $m c r A$ together with selected reference sequences were aligned with ClustalW (Larkin et al. 2007). Suitable evolutionary model was selected with ProtTest (Abascal et al. 2005). Maximum likelihood trees were constructed with PhyML (Guindon \& Gascuel 2003) with model LG+G+F. Bootstrap values were generated from 100 replicates in PhyML. Pairwise distance calculations of nucleotide $p m o A$ sequences were analyzed with MEGA 4.0 (Tamura $e t$ al. 2007). The $m c r A$ and $p m o A$ sequences have been submitted to the EMBL database under accession nos. FN564006-FN564029 ( $m c r A)$ and GQ279342-GQ279346 (pmoA).

\section{Statistical evaluation}

Methane fluxes between locations were compared by one-way analysis of variance (ANOVA).

Significance of pairwise differences was assessed by Tukey test. The effect of categorical variables depth, location and their interaction on potential $\mathrm{CH}_{4}$ production and oxidation were compared with generalized linear models (GLM). Tukey post hoc test was applied to determine which pairs of means differ significantly. Because location and depth had significant interactions, ANOVA followed by Tukey test was performed separately for each depth. Level of significance in all statistical analyses was $\mathrm{P}=0.05$.

We applied principal component analysis (PCA) to compare the four locations based on their environmental variables, i.e., long-term and momentary $\mathrm{WT}, \mathrm{CH}_{4}$ field emission and 
oxidation and production potential, coverage of Sphagnum and aerenchymatic plants, and pH. To examine variation in methanogen and MOB communities, we first applied detrended correspondence analysis (DCA). Based on the DCA showing rather small compositional variation, (ter Braak \& Prentice 1988) we applied redundancy analysis (RDA) to test which environmental variables best explained variation in methanogen and MOB communities. The significance of the above listed explanatory factors was assessed using Monte Carlo permutation test. The multivariate analyses were carried out with Canoco for Windows (ter Braak \& Smilauer 2002).

\section{Results}

\section{Methane emissions}

In the years $(2001-2004)$ preceding the sampling for microbial community analysis, the $\mathrm{CH}_{4}$ emissions from location $\mathrm{S} 4$, were substantial, averaging $73 \mathrm{mg} \mathrm{m}^{-2} \mathrm{day}^{-1}$ (Fig. 1). As a result of WT drawdown, the emissions were much smaller in the locations S3 $\left(22 \mathrm{mg} \mathrm{m}^{-2} \mathrm{day}^{-1}\right), \mathrm{S} 2(0.9$ $\mathrm{mg} \mathrm{m}^{-2}$ day $\left.^{-1}\right)$ and $\mathrm{S} 1$ (1.9 $\mathrm{mg} \mathrm{m}^{-2}$ day $^{-1}$; Fig. 1). Similarly to long term WT the emissions differed significantly between all pairs of locations $(\mathrm{P}=0.001-0.004)$ except for locations $\mathrm{S} 2$ and S1.

\section{Methane production and oxidation potential}

The wettest location $\mathrm{S} 4$ had the highest $\mathrm{CH}_{4}$ production potential at depths from 20 to $50 \mathrm{~cm}$ $(\mathrm{P}=0.001-0.036$, Fig. 2$)$ in correspondence with the flux rates recorded in earlier years. The S4 production was $43.2 \mathrm{nmol} \mathrm{g}_{\text {dry }}$ weight $^{-1}$ day $^{-1}$ compared to $0.4(\mathrm{~S} 3, \mathrm{p}=0.005), 4.0(\mathrm{~S} 2, \mathrm{p}=0.010)$ and $0.4(\mathrm{~S} 1, \mathrm{p}=0.005)$ at the depth of $20 \mathrm{~cm}$. The production potential of the three other dryer 
locations was much lower and did not differ between the locations at any depth. The laboratory measurements showed that location and depth significantly affected the $\mathrm{CH}_{4}$ production potential through the WT gradient $(\mathrm{p}<0.001)$.

The highest methane oxidation potential was observed in location S3, $561.2 \mathrm{nmol} \mathrm{g}$ dry weight $^{-1}$ day $^{-1}$, but the sampling depth influenced the oxidation potential $(p=0.004)$ in addition to location ( $\mathrm{p}=0.033$ ) (Fig. 2). In the top layer the potential was significantly higher in $\mathrm{S} 3$ than in $\mathrm{S} 2,62.2 \mathrm{nmol} g$ dry weight ${ }^{-1}$ day $^{-1}(\mathrm{p}=0.042)$ and S1, $28.9 \mathrm{nmol}_{\mathrm{g}}$ dry weight $^{-1}$ day $^{-1}(\mathrm{p}=0.031)$ and second highest in S4, 177,7 nmol g dry weight ${ }^{-1}$ day $^{-1}$. The dry S1 location had the lowest potential oxidation rate. The oxidation potential did not differ between locations in deeper peat layers.

\section{Environmental factors characterizing the WT gradient}

Principal component analyses (PCA) performed on the vegetation, potential $\mathrm{CH}_{4}$ production and oxidation, $\mathrm{CH}_{4}$ field emissions, $\mathrm{pH}$, and long term and momentary (date of sampling) water-table depth clearly separated the four sampling locations along the first principal axis (PC1 in Fig. 3a). With the provided measurements the second principal axis (PC2) separated all samples according to depth. Increase in long term WT, coverage of Sphagnum and aerenchymatic plants, high $\mathrm{CH}_{4}$ field emissions together with $\mathrm{CH}_{4}$ production potential characterized the pristine end of the PC1 (Fig. 3b). Decreasing momentary $\mathrm{WT}$ and $\mathrm{CH}_{4}$ oxidation potential together with increasing $\mathrm{pH}$ characterized the peat layers with increasing depth along PC2.

\section{Microbial communities involved in the $\mathrm{CH}_{4}$ cycle along the gradient}

T-RFLP fingerprinting of $m c r A$ representing methanogens resulted in twelve T-RFs (Table 1). In the RDA T-RFs 468 and 471 were combined since the large size of T-RFs prohibited reliable 
distinction between them. According to RDA the methanogen community structure showed highest correlation with methane production and coverage of aerenchymatic plants along the gradient (RD1 in Fig. 4a-c). The second RDA axis showed that the $\mathrm{pH}$ influenced the community structure according to depth. The first RDA axis separated the four locations when the methanogen communities at different depths were analyzed together with environmental factors (Fig. 4b). The top layers were most variable through the gradient, but deeper down they became more alike.

In the wet end of the gradient with higher $\mathrm{CH}_{4}$ production potential the methanogen diversity was highest with 8 to 10 T-RFs. The locations S2 and S1 sampled from three depths showed lower diversity with 6 T-RFs.

The occurrence of the T-RFs $115 \mathrm{bp}$ (Methanocellales), $272 \mathrm{bp}$ (putatively Methanosarcinaceae) and $298 \mathrm{bp}$ (Methanosarcinaceae) correlated most strongly with the wet location S4 (Fig. 4c, Fig. 5). In addition to identified methanogens, T-RF 193 bp affiliated with a cluster with no cultured representatives in the phylogenetic tree (Fig. 5). The T-RF $278 \mathrm{bp}$, representing Methanomicrobiales-associated Fen cluster, was one of two T-RFs prone to the dry end of the gradient despite of overall decrease in methanogen groups along the gradient.

In analysis of MOB communities, the broad specificity pmoA primer set A189f/A682r did not produce correct amplicons (Tuomivirta et al. 2009). Five different pmoA alleles (T, S, R, M, and O), all Methylocystis spp according to sequence comparisons, could, however, be isolated from the gradient by PCR-DGGE and sequencing with the A189f/A621r primer set (Table 2). RDA (Fig. 6a) of the pmoA alleles showed that their occurrence was best correlated with $\mathrm{CH}_{4}$ oxidation potential, $\mathrm{pH}$ and vegetation. Similarly to methanogen communities (Fig. 4a) the locations from wet to dry were separated along the first RDA axis, and the second RDA axis characterized the depth of the peat (Fig. 6b). The two wettest locations had similar MOB 
communities in their whole profile (Fig. 6b). The deep layers $(30-40 \mathrm{~cm})$ of the locations S4, S3 and S2 were also characterized by a similar MOB. The MOB community of the dry location S1 differed from the other sites. The $\mathrm{M}$ allele, dominating the wet end of the gradient (Fig. 6a) was identical to a previously detected Finnish fen sequence FJ930087 (Tuomivirta et al. 2009) and was most different from the other alleles with 11 to 12 point mutations. The $\mathrm{R}$ allele inhabiting the wetter part of the gradient was identical to sequences FJ930090 and FJ930091 of a Finnish fen (Tuomivirta et al. 2009), AY309209, a North-American fen (Nold, personal communication), and the sequence GQ121280 (Larmola et al. 2010) occurring in methane oxidizing community within Sphagnum mosses. Drying correlated with increasing abundances of alleles O, S and T. The $\mathrm{R}$ allele dominated the pristine location and the upper layer of the peat (Fig. 6a).

\section{Discussion}

Generally the study supports the five hypotheses concerning $\mathrm{CH}_{4}$ turnover in relation to detected microbial communities along WT drawdown gradient. The study of greenhouse gas turnover along a peatland WT gradient showed that drying appeared to cause a dramatic reduction in $\mathrm{CH}_{4}$ emissions and in potential $\mathrm{CH}_{4}$ production in agreement with our hypotheses 1 and 2. Despite more oxic conditions the methane oxidation also decreased substantially along the gradient. The phenomena supported our third hypothesis on the superior role of the availability of $\mathrm{CH}_{4}$ for the potential $\mathrm{CH}_{4}$ oxidation over the direct WT control. In agreement with the fifth hypothesis drying decreased the diversity of the methanogen communities and brought forth an adapted group of archaea, the Fen cluster methanogens, which was characteristic of dryer conditions. As hypothesized (hypothesis 4) the depth appeared to be an important factor for the community structure of methanogens and of methanotrophs. The depth effect in WT drawdown brought 
about a peculiar shift in methanotroph populations showing specific $p m o A$ allele types of Methylocystis bacteria distributed to specific locations in the gradient. Previously, at the same site, the $\mathrm{CO}_{2}$ flux increased from location $\mathrm{S} 4$ to $\mathrm{S} 1$ and fungi and bacteria benefited from the WT drawdown whereas actinobacteria did not (Jaatinen et al. 2008).

Separation of the four locations along the WT gradient and the sampling depths (peat layers) was clear and could statistically be explained by eight variables. The WT gradient was best described in PCA by coverage of aerenchymatic plants, high $\mathrm{CH}_{4}$ emissions at the wet end, coverage of Sphagnum moss and $\mathrm{CH}_{4}$ production potential in this order. $\mathrm{The} \mathrm{CH}_{4}$ oxidation was reduced as a consequence of WT drawdown but not as clearly as the production. This may well be indicative of the difference in the two processes of production (anaerobic) and the following consumption (aerobic) of $\mathrm{CH}_{4}$. The $\mathrm{CH}_{4}$ oxidation potential indeed correlated positively with the WT of the time of sampling and the coverage of Sphagnum, whereas production correlated with other variables like $\mathrm{pH}$ and emissions (Fig. 3b). The high oxidation in wet locations seemed to be coupled with high $\mathrm{CH}_{4}$ production potential. When more $\mathrm{CH}_{4}$ is potentially produced by methanogenic archaea, more is simultaneously oxidized by the methanotrophic bacteria.

Very recently methane oxidation was reported from 23 different Sphagnum species originating from a Finnish boreal mire site and the activity was related to a Methylocystis signature similar to the R allele of this study (Larmola et al. 2010). The correlation of the oxidation potential with Sphagnum coverage might be a direct regulation instead of a covariation with more pristine conditions.

The methanogen community structure according to T-RFLP analysis changed with decrease in diversity along the gradient. The maximum $\mathrm{CH}_{4}$ production potential for each vertical peat core correlated with the diversity of methanogens so that decreasing production was reflected in decreasing diversity. WT gradients have mainly been studied in meso- and 
microcosms (see, however, Talbot et al. 2010), and as far as we know reports from natural gradients combined with microbial community analysis of the $\mathrm{CH}_{4}$ are lacking. In agreement with our results from the gradient, experimental field studies in Canada (Strack et al. 2004) and in Ireland (Laine et al. 2009) have shown decrease in $\mathrm{CH}_{4}$ emission as a result of lowered WT. Short term effects of WT on carbon balance in pore water from acidic, oligotrophic mire have been reported from a mesocosm study (Blodau et al. 2004) where decreased $\mathrm{CH}_{4}$ production and emission was reported as a result of lower WT. Short term effect of drought (4 week) on the methanogen community structure in a bog and a fen mesocosm could not be observed (Kim et al. 2008), but a significant decrease in the $m c r A$ abundance was detected in the fen mesocosm. Sampling depth has been shown to affect the methanogen community structure in mires (Galand et al. 2002b) where the changing conditions with depth (oxygen and quality of growth substrates for the microbes active in methanogenesis) will select for methanogen groups. The RDA analysis of the methanogen communities together with environmental factors showed nicely how the locations differ at the surface, but become much alike in the deepest sampling layer where the conditions in the gradient apparently are more similar (Fig. 4b). The discrepancy of location $\mathrm{S} 2$ to the general trend may well be explained by larger $\mathrm{pH}$ variation at this location (results not shown) and lowest emissions telling that this location is the most disturbed one in the gradient.

The methanogen group most strongly associated with the pristine end of the gradient was Methanosarcinaceae. In the drier locations, Methanosarcinaceae T-RFs were less abundant or absent. This finding was surprising considering that many members Methanosarcinaceae are versatile methanogens that are able to use several different substrates for growth (Garcia et al. 2000). They also possess enzymes for detoxification of oxygen, which could favor their occurrence in the dry end of the gradient, which is the opposite of what was observed. Additional 
data, such as availability of methanogenic substrates along the gradient, would be required to better explain the disappearance of Methanosarcinaceae at the dry end. A minor group also found primarily at the wet end was an uncultured cluster (Mx cluster in Fig. 5) which has been detected in other wetland ecosystems (Juottonen et al. 2005; Castro et al. 2004; Smith et al. 2007) and in animal feces (Ufnar et al. 2007), and it has been proposed to form an entirely new order of methanogens (Mihajlovski et al. 2008). Only two methanogenic groups were typical to the dry end of the gradient, and they were affiliated with the Fen cluster which has commonly been found in Finnish mires (Juottonen et al. 2008). One member of this cluster, Methanoregula boonei, was isolated from an acidic bog and has the lowest $\mathrm{pH}$ optimum known for a methanogen (Bräuer et al. 2006). It is tempting to say that the Fen cluster/Methanoregula-type hydrogenotrophic methanogens are well adapted to the conditions of boreal fens characterized by changing WT and low $\mathrm{pH}$.

All detected MOBs were by pmoA sequence analysis found to be of the Methylocystis genus, but differed by minute changes, point mutations, in the gene (Table 2). This suggests a phylogenetically very narrow MOB population of this fen. RDA showed that the occurrence of the five alleles was clearly dependent on location and peat layer in the gradient. It can be assumed that before WT drawdown, when the whole site was botanically a homogenous fen, all the locations had a similar MOB population with dominating alleles $\mathrm{R}$ and $\mathrm{T}$ in surface peat and then changing to $\mathrm{T}$ and $\mathrm{M}$ alleles in the deeper peat. Continual drainage of the fen has a selective pressure on MOB. The R allele was lost upon drying since methanotrophy in Sphagnum mosses is only related to high WT (Larmola et al. 2010). For reasons we do not know the most different $\mathrm{M}$ allele, in respect to other ones, disappears in WT drawdown and is replaced by the $\mathrm{O}$ and $\mathrm{S}$ alleles through out the peat layer. The $\mathrm{S}$ allele could originate from the generalist $\mathrm{T}$ through a 
single silent point mutation in $p m o A$. The $\mathrm{O}$ has probably been introduced to the location as it contains four silent point mutations in respect with $\mathrm{S}$.

Methylocystis was a dominating genus also in Russian and German bogs, which showed that $60-95 \%$ of MOB belonged to type II with Methylocystis being the dominant genus (Dedysh et al. 2003). A study, in which stable isotope probing (SIP) with PLFA, mRNA and microarray methods were used, revealed the dominance of type II genera Methylocystis and Methylosinus in blanket peat samples from England (Chen et al. 2008). Bearing in mind that also Sphagnum species possess Methylocystis (Larmola et al. 2010), one can say that it most likely dominates in northern peatlands.

With regard to climate change effect on boreal fens, the average drop in WT between location S4 (wet fen) and location S3 (semi-wet) was ca. $6 \mathrm{~cm}$. This was accompanied by a statistically significant drop in potential $\mathrm{CH}_{4}$ production together with a reduction in emissions from previous years. The potential oxidation changed in the other direction with increasing amounts of $\mathrm{CH}_{4}$ oxidized at location $\mathrm{S} 3$ as compared to location $\mathrm{S} 4$. This would indicate that already a small, $6 \mathrm{~cm}$, WT drawdown will change the $\mathrm{CH}_{4}$ turnover. The methanogen community structure most clearly shifted between locations S3 and S2 and the distribution of the methanotrophic allele types is also changing most clearly in this part of the gradient. It can, however, be stated that as the underlaying microbial communities are changing with a $12 \mathrm{~cm}$ drop in WT their activity is already altered after the 6-cm initial drop in WT.

Comparison of behavior of methanogens and methanotrophs in the WT gradient using $\mathrm{CH}_{4}$ production and oxidation measurements showed a difference in sensitivity to changing conditions. Much of the methanogenic activity is evidently lost already in the semi-wet location $\mathrm{S} 3$ and after that decreases drastically, whereas the methanotroph potential activity is high in the wet locations and decreases much less in the dryer locations. This can be explained by more oxic 
conditions that should favor these aerobic bacteria. The drop is best explained by the lack of substrate; $\mathrm{CH}_{4}$.

As a general conclusion, we have been able to show that even a minor WT drawdown, mimicking the climate change impact affects the dynamics of $\mathrm{CH}_{4}$ production and oxidation in a mire. This study thus shows how ecohydrology shapes the dynamics of mires changing the plant community structures, and has a drastic effect on the microbial communities that are the basis for the environmentally important function of greenhouse gas turnover.

\title{
Acknowledgements
}

We thank Sirpa Tiikainen for the valuable laboratory help with MOB. This study was financed by the Academy of Finland (project number 109816).

\section{References}

Abascal F, Zardoya R, Posada D (2005) ProtTest: selection of best-fit models of protein evolution. Bioinformatics, 21, 2104.

\author{
Altschul S, Madden T, Schaeffer A, Zhang J, Zhang Z, Miller W, Lipman D (1997) Gapped \\ BLAST and PSI-BLAST: A new generation of protein database search programs. Nucleic acids \\ research, 25, 3389-3402. \\ Basiliko N, Yavitt J, Dees P, Merkel S (2003) Methane biogeochemistry and methanogen \\ communities in two northern peatland ecosystems, New York State. Geomicrobiology Journal, \\ 20, $563-577$. \\ Blodau C, Basiliko N, Moore TR (2004) Carbon turnover in peatland mesocosms exposed to \\ different water table levels. Biogeochemistry, 67, 331-351.
}


Braak CJF, Smilauer P (2002) CANOCO reference manual and CanoDraw for Windows user's guide: software for canonical community ordination (version 4.5).

Bräuer SL, Cadillo-Quiroz H, Yashiro E, Yavitt JB, Zinder SH (2006) Isolation of a novel acidiphilic methanogen from an acidic peat bog. Nature, 442, 192-194.

Castro H, Ogram A, Reddy KR (2004) Phylogenetic characterization of methanogenic assemblages in eutrophic and oligotrophic areas of the Florida Everglades. Applied and environmental microbiology, 70, 6559-6568.

Chen Y, Dumont MG, Neufeld JD, et al (2008) Revealing the uncultivated majority: combining DNA stable-isotope probing, multiple displacement amplification and metagenomic analyses of uncultivated Methylocystis in acidic peatlands. Environmental microbiology, 10, 2609-2622. Dahlin T, Minkkinen K, Penttilä T (2003) Methane emissions from a northern boreal pine fen along water table gradient - preliminary results. In Proceedings of Sixth Finnish Conference of Environmental Sciences. Joensuu, May 8-9, 2003. Current Perspectives in Environmental Science and Technology. Honkanen JO and Koponen PS (eds). University of Joensuu, Joensuu, Finland.

Dedysh SN (2009) Exploring Methanotroph Diversity in Acidic Northern Wetlands: Molecular and Cultivation-Based Studies. Microbiology, 78, 655-669.

Dedysh SN, Dunfield PF, Derakshani M, Stubner S, Heyer J, Liesack W (2003) Differential detection of type II methanotrophic bacteria in acidic peatlands using newly developed 16S rRNA-targeted fluorescent oligonucleotide probes. FEMS microbiology ecology, 43, 299-308. Edwards C, Hales B, Hall G, et al (1998) Microbiological processes in the terrestrial carbon cycle: methane cycling in peat. Atmospheric Environment, 32, 3247-3255. 
Galand PE, Fritze H, Conrad R, Yrjälä K (2005) Pathways for methanogenesis and diversity of methanogenic archaea in three boreal peatland ecosystems. Applied and environmental microbiology, 71, 2195-2198.

Galand PE, Fritze H, Yrjälä K (2003) Microsite-dependent changes in methanogenic populations in a boreal oligotrophic fen. Environmental microbiology, 5, 1133-1143.

Galand PE, Juottonen H, Fritze H, Yrjala K (2005) Methanogen communities in a drained bog: effect of ash fertilization. Microbial ecology, 49, 209-17.

Galand PE, Saarnio S, Fritze H, Yrjälä K (2002a) Depth related diversity of methanogen Archaea in Finnish oligotrophic fen. FEMS microbiology ecology, 42, 441-449.

Galand PE, Saarnio S, Fritze H, Yrjälä K (2002b) Depth related diversity of methanogen Archaea in Finnish oligotrophic fen. FEMS microbiology ecology, 42, 441-449.

Garcia JL, Patel BK, Ollivier B (2000) Taxonomic, phylogenetic, and ecological diversity of methanogenic Archaea. Anaerobe, 6, 205-226.

Gitay H, Brown S, Easterling W, et al (2001) Ecosystems and their goods and services. In: Climate change 2001; impacts, adaptation, and vulnerability (eds McCarthy JJ, Canziani OF, Leary NA, Dokken DJ, White KS), Cambridge University Press, Cambridge, United Kingdom (GBR), United Kingdom (GBR).

Gorham E (1991) Northern peatlands: role in the carbon cycle and probable responses to climatic warming. Ecological Applications, 1, 182-195.

Guindon S, Gascuel O (2003) A simple, fast, and accurate algorithm to estimate large phylogenies by maximum likelihood. Systematic Biology, 52, 696-704.

Hanson R, Hanson T (1996) Methanotrophic bacteria. Microbiology and Molecular Biology Reviews, 60, 439. 
Holmes A, Costello A, Lidstrom M, Murrell J (1995) Evidence that particulate methane monooxygenase and ammonia monooxygenase may be evolutionarily related. FEMS microbiology letters, 132, 203-208.

Jaatinen K, Laiho R, Vuorenmaa A, del Castillo U, Minkkinen K, Pennanen T, Penttilä T, Fritze H (2008) Responses of aerobic microbial communities and soil respiration to water-level drawdown in a northern boreal fen. Environmental microbiology, 10, 339-353.

Jaatinen K, Tuittila E-S, Laine J, Yrjala K, Fritze H (2005) Methane-Oxidizing Bacteria in a Finnish Raised Mire Complex: Effects of Site Fertility and Drainage. Microbial ecology, 50, 429439.

Juottonen H, Tuittila ES, Juutinen S, Fritze H, Yrjala K (2008) Seasonality of rDNA-and rRNAderived archaeal communities and methanogenic potential in a boreal mire. The ISME Journal, 2, $1157-1168$.

Juottonen H, Galand PE, Tuittila ES, Laine J, Fritze H, Yrjala K (2005) Methanogen communities and Bacteria along an ecohydrological gradient in a northern raised bog complex. Environmental microbiology, 7, 1547-1557.

Kim SY, Lee SH, Freeman C, Fenner N, Kang H (2008) Comparative analysis of soil microbial communities and their responses to the short-term drought in bog, fen, and riparian wetlands. Soil Biology and Biochemistry, 40, 2874-2880.

Laine A, Byrne KA, Kiely G, Tuittila E-S (2009) The effect of altered water level on carbon fluxes in a blanket bog. SUO 60, 65-83.

Laine J, Vasander H (2005) Suotyypit ja niiden tunnistaminen.[Mire site types and their identification.].

Laine J, Vasander H, Laiho R (1995) Long-term effects of water level drawdown on the vegetation of drained pine mires in southern Finland. Journal of Applied Ecology, 32, 785-802. 
Larkin M, Blackshields G, Brown N, et al (2007) Clustal W and Clustal X version 2.0. Bioinformatics, 23, 2947.

Larmola T, Tuittila E-S, Tiirola M, Nykänen H, Martikainen PJ, Yrjälä K, Tuomivirta T, Fritze H (2010) The role of Sphagnum mosses in the methane cycling of a boreal mire. Ecology (in press). Luton PE, Wayne JM, Sharp RJ, Riley PW (2002) The mcrA gene as an alternative to 16S rRNA in the phylogenetic analysis of methanogen populations in landfill. Microbiology, 148, 35213530.

McDonald I, Upton M, Hall G, Pickup R, Edwards C, Saunders J, Ritchie D, Murrell J (1999) Molecular ecological analysis of methanogens and methanotrophs in blanket bog peat. Microbial ecology, 38, 225-233.

Merilä P, Galand PE, Fritze H, Tuittila E, Kukko-Oja K, Laine J, Yrjälä K (2006) Methanogen communities along a primary succession transect of mire ecosystems. FEMS microbiology ecology, 55, 221-229.

Mihajlovski A, Alric M, Brugère JF (2008) A putative new order of methanogenic Archaea inhabiting the human gut, as revealed by molecular analyses of the mcrA gene. Research in microbiology, 159, 516-521.

Popp TJ, Chanton JP, Whiting GJ, Grant N (2000) Evaluation of methane oxidation in the rhizosphere of a Carex dominated fen in northcentral Alberta, Canada. Biogeochemistry, 51, 259281.

Putkinen A, Juottonen H, Juutinen S, Tuittila ES, Fritze H, Yrjälä K (2009) Archaeal rRNA diversity and methane production in deep boreal peat. FEMS microbiology ecology, 70, 87-98. Raghoebarsing AA, Smolders AJP, Schmid MC, et al (2005) Methanotrophic symbionts provide carbon for photosynthesis in peat bogs. Nature, 436, 1153-1156. 
Roulet N, Moore T, Bubier J, Lafleur P (1992) Northern fens: methane flux and climatic change. Tellus, 44, 100-105.

Rydin H, Jeglum J, Hooijer A (2006) The biology of peatlands. Oxford University Press, USA, . Smith JM, Castro H, Ogram A (2007) Structure and function of methanogens along a short-term restoration chronosequence in the Florida Everglades. Applied and Environmental Microbiology, 73, 4135.

Strack M, Waddington JM, Rochefort L, Tuittila E-S (2006) Response of vegetation and net ecosystem carbon dioxide exchange at different peatland microforms following water table drawdown. Journal of Geophysical Research, 111, 1-10.

Strack M, Waddington JM, Tuittila E-S (2004) Effect of water table drawdown on peatland methane dynamics: Implications for climate change. Global Biogeochemical Cycles, 18, 1-7. Sundh I, Nilsson M, Granberg G, Svensson B (1994) Depth distribution of microbial production and oxidation of methane in northern boreal peatlands. Microbial ecology, 27, 253-265. Talbot J, Richard PJH. Roulet NT, Booth R (2010) Assessing long-term hydrological and vegetation changes following drainage in a bog using paleoecological reconstructions and a hydrosequence. Vegetation Science (in press).

Tamura K, Dudley J, Nei M, Kumar S (2007) MEGA4: molecular evolutionary genetics analysis (MEGA) software version 4.0. Molecular biology and evolution, 24, 1596.

ter Braak CJF, Prentice IC (1988) A theory of gradient analysis. Advances in Ecological Research, 18, 1-3.

Tuomivirta TT, Yrjälä K, Fritze H (2009) Quantitative PCR of pmoA using a novel reverse primer correlates with potential methane oxidation in Finnish fen. Research in microbiology, 160, $751-756$. 
Ufnar JA, Wang SY, Ufnar DF, Ellender R (2007) Methanobrevibacter ruminantium as an indicator of domesticated-ruminant fecal pollution in surface waters. Applied and Environmental Microbiology, 73, 7118 .

Weltzin JF, Bridgham SD, Pastor J, Chen J, Harth C (2003) Potential effects of warming and drying on peatland plant community composition. Global Change Biology, 9, 141-151.

Weltzin JF, Pastor J, Harth C, Bridgham SD, Updegraff K, Chapin CT (2000) Response of bog and fen plant communities to warming and water-table manipulations. Ecology, 81, 3464-3478. Yavitt J, Lang G, Downey D (1988) Potential Methane Production and Methane Oxidation Rates in Peatland Ecosystems of the Appalachian Mountains, United States. Global Biogeochemical Cycles, 2, 253-268.

Yeates C, Gillings MR, Davison AD, Altavilla N, Veal DA (1998) Methods for microbial DNA extraction from soil for PCR amplification. Biological Procedures Online, 1, 40-47. 
Table 1 Identification of T-RFs detected in analysis methanogens in the mires forming a water table (WT) gradient. The occurrence of PCR-T-RFLP detected methanogens in the WT gradient formed by the four locations S4-S1 and the relative abundance of T-RFs in each location.

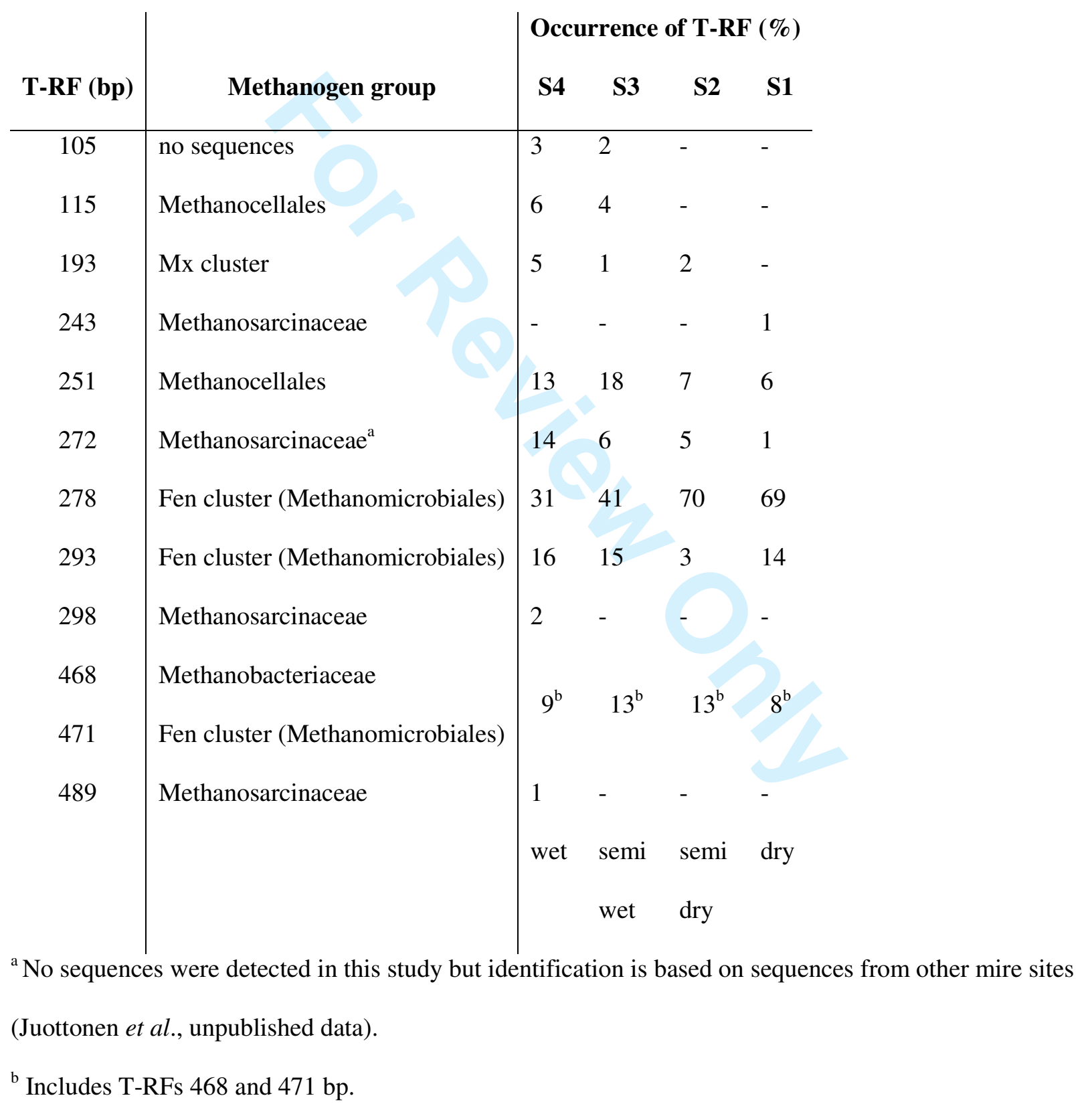


Table 2 Number of point mutations (integers) between different $p m o A$ allele sequences and standard errors (in parenthesis) of pairwise distance calculations. Accession numbers in Genbank are GQ279342 (T), GQ279343 (S), GQ279344 (R), GQ279345 (M) and GQ279346 (O), respectively.

\begin{tabular}{|c|c|c|c|c|c|}
\hline $\begin{array}{l}\text { Sequence } \\
\text { of } p m o A\end{array}$ & & & & & \\
\hline $\mathrm{O}$ & 5 & 4 & 7 & 11 & \\
\hline$M$ & 12 & 11 & 12 & & \\
\hline $\mathrm{R}$ & 2 & 3 & & & \\
\hline \multirow{3}{*}{$\begin{array}{l}\mathrm{S} \\
\mathrm{T}\end{array}$} & 1 & & & & \\
\hline & & & & & \\
\hline & $\mathrm{T}$ & $S$ & $\mathrm{R}$ & $M$ & O \\
\hline $\mathrm{T}$ & & {$[0.00198]$} & {$[0.00286]$} & [0.00977 ] & {$[0.00513]$} \\
\hline$S$ & 0.00122 & & {$[0.00376]$} & [0.00918] & {$[0.00455]$} \\
\hline $\mathrm{R}$ & 0.00244 & 0.00367 & & {$[0.01011]$} & [0.00648 ] \\
\hline M & 0.01518 & 0.0139 & 0.01522 & & [0.00944 ] \\
\hline 0 & 0.00616 & 0.00492 & 0.00867 & 0.01382 & \\
\hline
\end{tabular}


Fig. 1 Average methane emission 2001-2004 from the four locations forming a water table (WT) gradient, from wet fen location S4 to dry forested location S1.

Fig. 2 (a) The potential methane production, (b) the potential methane oxidation in the four locations S4 - S1. The depths are given as distance from the surface of the mires.

Fig. 3 (a) Principal component analysis (PCA) of environmental factors, emissions, vegetation, water table (WT) for locations $\mathrm{S} 4$ to $\mathrm{S} 1$ coupled with $\mathrm{CH}_{4}$ production and oxidation. The direction of the arrow describes the correlation between measured factors. The length of the arrow gives the degree of explanation of each variable in the ordination. The two first principal components together explained $55.3 \%$ of the variation. Eigenvalues of the first and second axis were 0.366 and 0.186 , respectively. (b) Score plot of the PCA.

Fig. 4 (a) Redundancy analysis (RDA) of statistically significant environmental factors and methanogen communities. The length of an arrow describes the degree of explanation of environmental factor. The first two axes explained $28.0 \%$ of the compositional variation. (b) RDA of methanogen phylotypes (T-RFs) at different depths and environmental factors. (c) RDA of T-RFs detected in the water table (WT) gradient. The length of arrow describes how well the phylotype correlates with locations in the gradient.

Fig. 5 Maximum likelihood tree of partial mcrA sequences (128 aa) from Suonukkasuo fen clones (in bold) and reference methanogen sequences. Size of terminal restriction fragment is indicated for each group. Scale indicates $10 \%$ sequence divergence. Nodes with bootstrap values $>95 \%$ are marked with filled circles and $>75 \%$ with open circles. The tree was rooted with Methanopyrus 


\author{
kandleri. In bold sequence names Suon1, Suon2 and Suon4 refer to locations S1, S2 and S4 of \\ the water table gradient.
}

Fig. 6 (a) RDA of methanotoph pmoA alleles showing correlation strength (length of arrow) with statistically significant environmental factors. The first two axes explained $47.1 \%$ of the compositional variation. (b) The change in methanotroph communities according to depth and environmental factors picturing the WT gradient. 
1

2

3

4

5

6

7

8

9

10

11

12

13

14
15

16

17

18

19

20

21

22

23

24

25

26

27

28

29

30

31

32

33

34

35

36

37

38

39

40

41

42

43

44

45

46

47

48

49

50

51

52

53

54

55

56

57

58

59

60

$x$

$206 \times 103 \mathrm{~mm}(600 \times 600 \mathrm{DPI})$ 


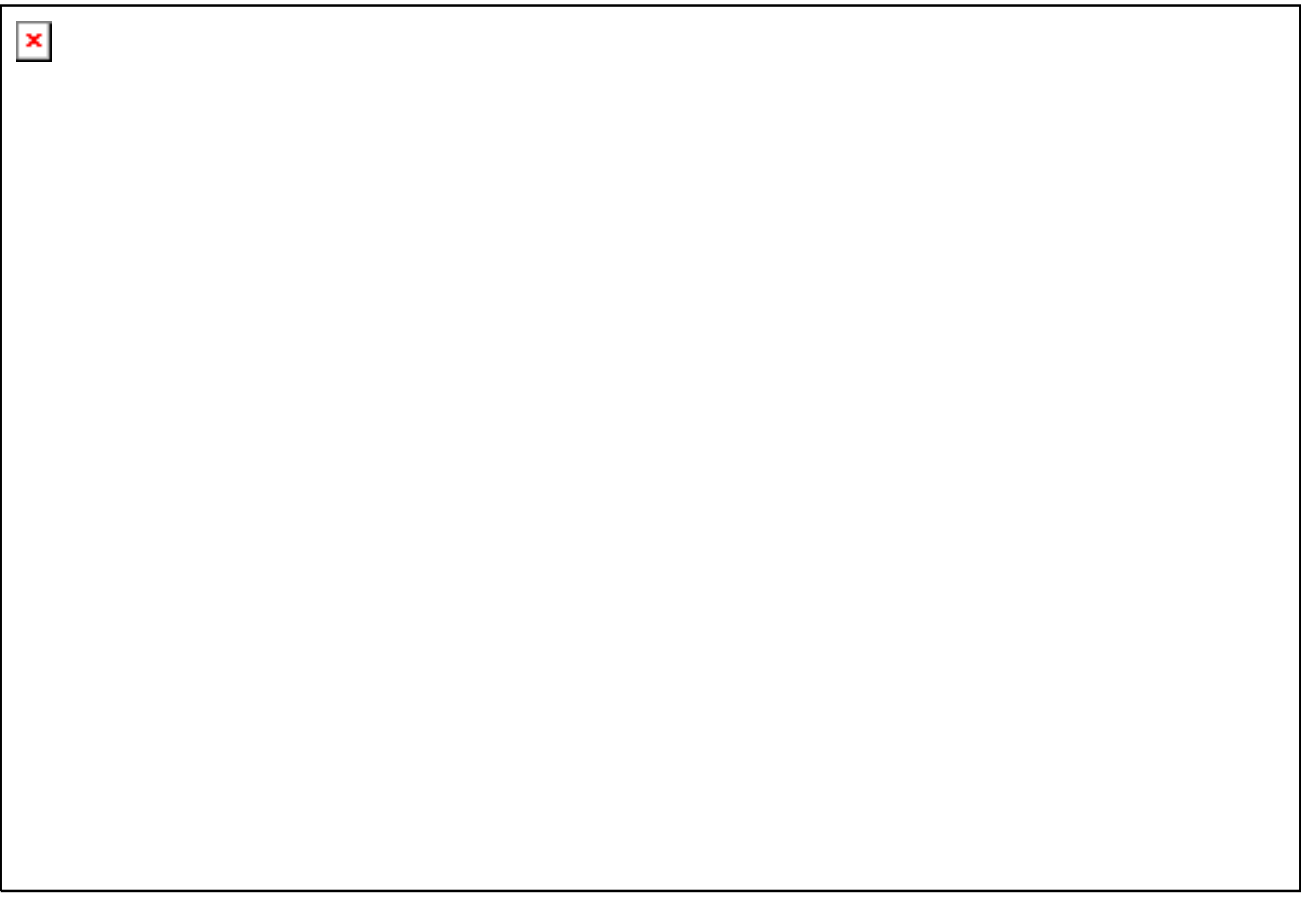

$195 \times 133 \mathrm{~mm}(600 \times 600 \mathrm{DPI})$ 
$x$

$166 \times 167 \mathrm{~mm}(600 \times 600 \mathrm{DPI})$ 
1

2

3

4

5

6

7

8

9

10

11

12

13

14

15

16

17

18

19

20

21

22

23

24

25

26

27

28

29

30

31

32

33

34

35

36

37

38

39

40

41

42

43

44

45

46

47

48

49

50

51

52

53

54

55

56

57

58

59

60 $x$

$166 \times 135 \mathrm{~mm}(600 \times 600 \mathrm{DPI})$ 


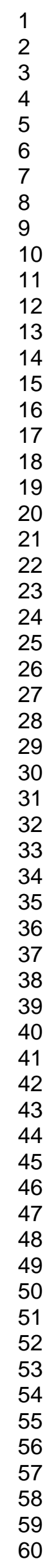

$x$

$196 \times 114 \mathrm{~mm}(600 \times 600 \mathrm{DPI})$ 
$x$

$177 \times 122 \mathrm{~mm}(600 \times 600 \mathrm{DPI})$ 


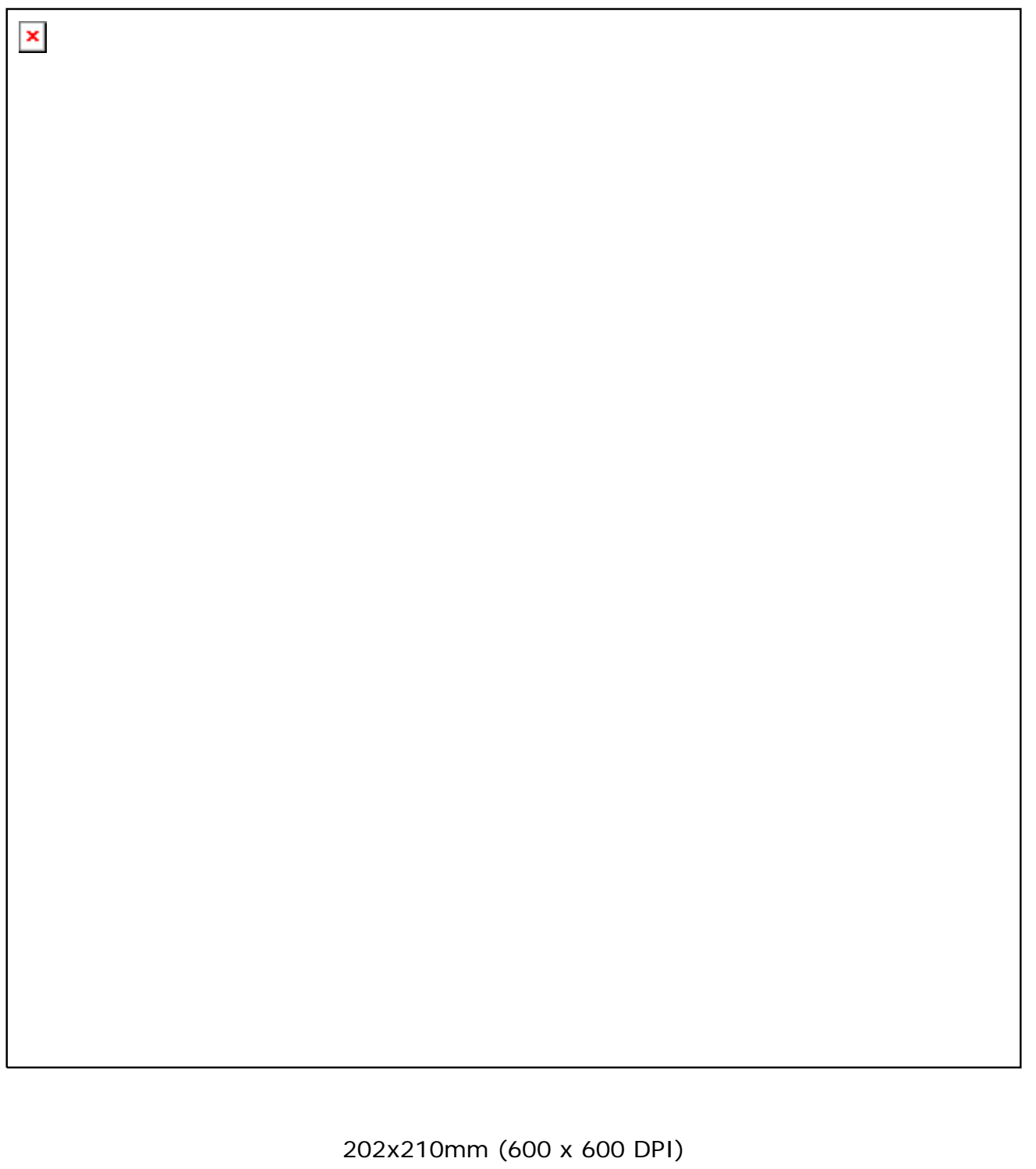

1

2

3

4

5

6

7

8

9

10

11

12

14

15

16

17

18

19

20

22

23

24

25

26

27

29

30

31

32

33

34

35

36

37

41

42

43

44

45

46

47

48

49

50

51

52

53

54

55

56

57

58

59

60
$202 \times 210 \mathrm{~mm}(600 \times 600 \mathrm{DPI})$ 
$x$

10

11

12

13

14

15

16

17

18

19

20

21

22

23

24

25

26

27

28

29

30

31

32

33

34

35

36

37

38

39

40

41

42

43

44

45

46

47

48

49

50

51

52

53

54

55

56

57

58

59

60

$157 \times 217 \mathrm{~mm}(600 \times 600 \mathrm{DPI})$ 
1

2

3

4

5

6
7

8

9

10

11

13

14

15

16

17

19

20

21

23

24

25

26

27

29

30

31

32

33

34

35

36

37

38

39

40

41

42

43

44

45

46

47

48

49

50

51

52

53

54

55

56

57

58

59

60

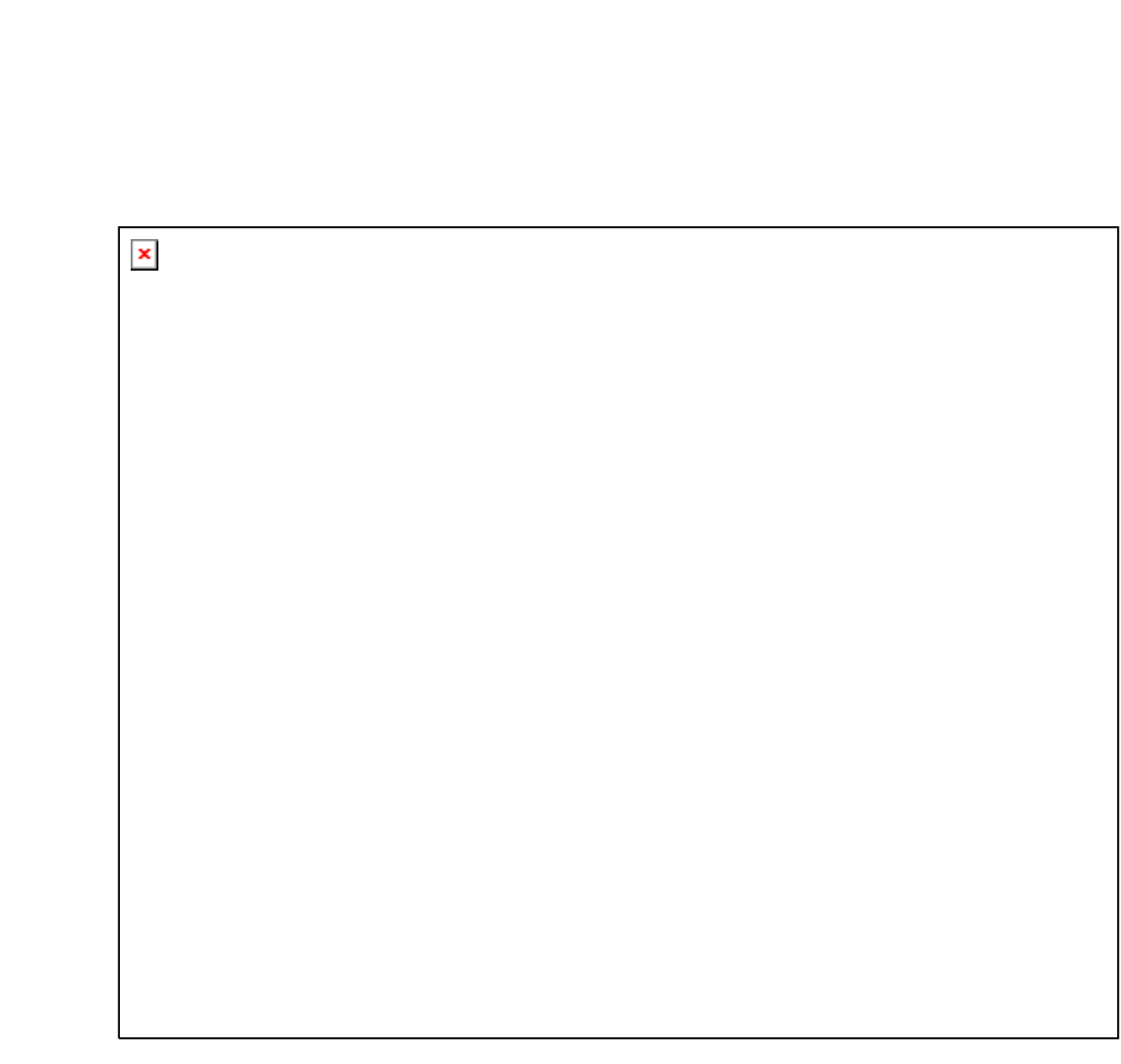

$171 \times 138 \mathrm{~mm}(600 \times 600 \mathrm{DPI})$ 